\title{
Water isotope characteristics of a flood: Brisbane River, Australia
}

\begin{tabular}{|r|l|}
\hline Journal: & Hydrological Processes \\
\hline Manuscript ID & HYP-14-0832.R2 \\
\hline Wiley - Manuscript type: & Research Article \\
\hline Date Submitted by the Author: & n/a \\
\hline Keywords: & deuterium, d180, storm, nutrients, sediment, floodwater \\
\hline & $\begin{array}{l}\text { Adame, Maria Fernanda; Griffith University, Australian Rivers Institute } \\
\text { Bunn, Stuart; Griffith University, Australian Rivers Institute }\end{array}$ \\
\hline
\end{tabular}

SCHOLARONE $^{\text {m }}$
Manuscripts 
1

2

3

4

5

6

7

8

9

10

11

12

13

14

15

16

17

18

19

20

21

22

23

24

25

26

27

28

29

30

31

32

33

34

35

36

37

38

39

40

41

42

43

44

45

46

47

48

49

50

51

52

53

54

55

56

57

58

59

60

\section{Water isotope characteristics of a flood: Brisbane River, Australia}

2 Adame, M.F.*, B. Fry, S.E. Bunn

3

4 Australian Rivers Institute, Griffith University, Nathan, 4111, QLD, Australia

5

6

7

8

$9 \quad{ }^{*}$ Corresponding author

10 f.adame@griffith.edu.au

$11+61737357101$ ext. 57101

12 Fax: +61737357615

13

14

15

16

http://mc.manuscriptcentral.com/hyp 


\section{Abstract}

2 Flooding associated with tropical storms can cause extreme perturbations in riverine and

3 coastal ecosystems. Measuring isotope variability of tropical storm events can help investigate

4 the impacts of flooding. We measured the water isotope composition $\left(\delta D\right.$ and $\left.\delta^{18} O\right)$ of rain and

5 associated floodwater collected during two storms and subsequent major and minor flooding

6 events in the subtropical coast of eastern Australia. Compared to baseline regional rainfall

7 isotope values of $-15.0 \pm 1.9 \%$ for $\delta \mathrm{D}$ and $-3.3 \pm 0.2 \%$ for $\delta^{18} \mathrm{O}$, floodwater had lower values

8 with $-33.8 \pm 2.5 \%$ o $\delta$ and $-5.1 \pm 0.4 \% \circ \delta^{18} \mathrm{O}$ for the major flood and $-29.4 \pm 1.0 \%$ o $\delta$ and $-4.6 \pm$

$9 \quad 0.1 \% \delta^{18} \mathrm{O}$ for the minor flood. The low isotope composition of the floodwater was associated

10 with the transport of large quantities of suspended sediments, with sediment loads 30 to 70

11 times larger than during base flow conditions. Floods carried up to $35 \%$ of the annual

12 phosphorus and up to $208 \%$ of the currently calculated average annual nitrogen load of the

13 Brisbane River. The dramatic changes caused by a rapid increase in discharge from 2 to 2,015

$14 \mathrm{~m}^{3} \mathrm{~s}^{-1}$ over two days in the major flood would have major consequences in riverine and coastal

15 ecosystems of the region. These changes could potentially be traced using the isotope

16 composition of the floodwaters.

18 Keywords: deuterium; $\delta^{18} \mathrm{O}$; storm; nutrients; suspended sediment; floodwater 


\section{Introduction}

The hydrogen and oxygen isotope compositions of water $\left(\delta \mathrm{D}\right.$, deuterium, and $\left.\delta^{18} \mathrm{O}\right)$

3 have long been used to study hydrological and climatological processes (Gat, 1996). More

4 recently, the use of $\delta \mathrm{D}$ and $\delta^{18} \mathrm{O}$ has expanded in many areas. For instance, water isotopes

5 have been used to assess sources of water for plants (Dawson et al., 2002) and to detect

6 migration patterns of birds in North America (Hobson and Wassenaar, 1997). Water isotopes

7 have also been used in forensics to uncover, for example, the place of origin of illegally hunted

8 wildlife (Bowen et al., 2005), or to trace the place of origin of a commercial product, such as

9 milk (Ehtesham et al., 2013). There is great potential for future use of $\delta D$ and $\delta^{18} \mathrm{O}$ in the many

10 fields where water is the underlying driver of change.

Hydrological, ecological and forensic studies have benefited from long-term programs

13 that monitor isotope variation in precipitation around the world (e.g. Global Network for

14 Isotopes in Precipitation, GNIP) and produce gridded datasets (Bowen, 2014). However, in

15 some locations, the isotope datasets have low spatial resolution, and the temporal sampling is

16 too coarse (e.g. monthly sampling) to detect isotope variations that occur within a relatively

17 short period of time (e.g. days), such as during storms (Araguás-Araguás et al., 2000). Storms

18 have been recognized as the most important factor affecting isotope variability within

19 precipitation of tropical regions (Kurita et al., 2009; Lachniet and Patterson 2009). Therefore, it

20 is of strong interest to measure isotope variability during short-lasting, but powerful storm

21 events that could explain the long-term rainfall isotope variability within the tropics.

The atmospheric moisture during tropical storms has a specific isotope composition with

24 very low $\delta \mathrm{D}$ and $\delta^{18} \mathrm{O}$ values that cannot be fully explained by usual assumptions of

25 precipitation and temperature (Gat, 1996). The distinctive isotope composition of tropical 
1 storms causes deviations of the seasonal isotope composition of rainfall. For example, in

2 southwest Australia, aseasonal strong rainfall events have an isotope composition significantly

3 lower than the annual minimum (Turner et al., 1987). Tropical storms in Central Amazon have

$4 \delta^{18} \mathrm{O}$ values approaching $-10 \%$ (Matsui et al.,1983), much lower than the annual range of

5 values of -2 to $2 \%$. Similarly, water isotope values near $-6.5 \%$ for $\delta^{18} \mathrm{O}$ have been measured

6 during tropical storms and low-pressure systems in Puerto Rico; these values are lower than

7 the annual range of 0 to $-3 \%$ (Scholl et al., 2009). These low values have been explained by

8 the so-called "amount effect" with lower values associated with higher rainfall amounts

9 (Dansgaard, 1964), and more recently, by cloud altitude and atmospheric condensation

10 temperature (Scholl et al., 2009). The characteristic isotope composition of rainfall during

11 storms generates an almost immediate response in the isotope composition of the river flow

12 (Turner et al., 1987). However, there are only a handful of published studies that provide

13 values of water isotopes of rainfall during tropical storms and none, as far as we know, for

14 floodwaters. In this study, we provide the water isotope composition $\left(\delta \mathrm{D}\right.$ and $\left.\delta^{18} \mathrm{O}\right)$ of rain and

15 associated floodwater collected during two storms and subsequent floods in the subtropical

16 coast of eastern Australia.

Floods can move large amount of nutrients and sediments into riverine and coastal ecosystems (Mitchell et al.,1997). Large nutrient and sediment loads can cause cyanobacterial

20 blooms, hypoxia, seagrass loss and coral reef degradation (Hallock and Schlager, 1996;

21 Campbell and McKenzie, 2004; Paerl, 2008). In this study, we augment information about the

22 isotope values of rain and floodwater with the physicochemical measurements of the

23 floodwater, including nutrient and sediment loads. This information could be used in ecological

24 studies in riverine and coastal ecosystems that use the isotopic composition of water to trace 25 the impacts of flooding. 
2 Methods

3 Study Area

4 Samples were collected in the Brisbane River catchment in Southeast Queensland,

5 Australia (Fig. 1). The region is classified as subtropical, experiencing moderate temperatures

6 year round, with a mean annual maximum temperature of $25.4^{\circ} \mathrm{C}$ and a mean annual minimum

7 of $15.7^{\circ} \mathrm{C}$ (Australian Bureau of Meteorology, ABM 1951-2000). The climate is characterized

8 by a moderately cold and dry winter with an average total rainfall of $64 \mathrm{~mm}$ and monthly mean

9 temperature of $22.3^{\circ} \mathrm{C}$ (June to August), and a hot and wet summer with a total rainfall of 597

$10 \mathrm{~mm}$ and a monthly mean temperature of $30.0^{\circ} \mathrm{C}$ (December to February). The hottest month is

11 January with a monthly mean of $30.2^{\circ} \mathrm{C}$ and the coldest months are June and July, both with a

12 monthly mean of $21.9^{\circ} \mathrm{C}$. The average total annual rainfall for the region is $1,186 \mathrm{~mm}(\mathrm{ABM}$,

13 Brisbane Station, 1999-2015 for temperature and 1951-2000 for rainfall).

14

15

16

17

The Brisbane River is 344 km long with a catchment area of $12,643 \mathrm{~km}^{2}$ (Ozcoasts, 2015). The mean, minimum and maximum monthly discharge rates from the Brisbane River are 26, 7 and $122 \mathrm{~m}^{3} \mathrm{~s}^{-1}$, respectively (State of Queensland, Department of Natural Resources and Mines, DERM, Station 143001C, Brisbane River at Savages Crossing, 1958-2015). The River has a 100-year recurrence interval flood $\left(Q_{100}\right)$ of $16,437 \mathrm{~m}^{3} \mathrm{~s}^{-1}$ (Shellberg and Brooks, 2007). The Brisbane River can be classified as hydrologically extreme with extreme flash flood behaviour and large annual variability in peak discharge (coefficient of variation of annual volume $=113 \%$; Shellberg and Brooks, 2007). The Brisbane River is dammed by the Wivenhoe Dam, forming Lake Wivenhoe, which is connected and managed conjunctively with Somerset lake, formed by the damming of Stanley River (Fig. 1). The Brisbane River has eight main tributaries: Stanley River, Breakfast Creek, Moggil Creek, Bulimba Creek, Norman 
1 Creek, Oxley Creek, Bremer River and Lockyer Creek, with the Lockyer Creek joining the

2 Brisbane River downstream of the dam (Fig. 1).

3

4

5 agriculture, grazing, water storage and urban development (Healthy Waterways, 2014). Fine

6 suspended sediment load in the Brisbane River is estimated to be around 247 kilotonnes $\mathrm{yr}^{-1}$

7 (Ozcoasts, 2015). Nutrient loads are estimated at 314 tonnes $\mathrm{yr}^{-1}$ for dissolved phosphorus

8 (P), 1,687 tonnes $\mathrm{yr}^{-1}$ for fine sediment $\mathrm{P}, 1,686$ for dissolved nitrogen $(\mathrm{N})$ and 1,473 tonnes $\mathrm{yr}^{-}$

$9{ }^{1}$ for fine sediment $\mathrm{N}$ (Ozcoasts, 2015).

11 Methods

On the 24th of January 2013, tropical storm Oswald crossed the eastern coast of Australia and caused intense rainfall in a short period. In some locations, rainfall in excess of $1,000 \mathrm{~mm}$ was measured in 96 hours resulting in moderate to major flooding (ABM, 2013). A historical peak flood of $9 \mathrm{~m}$ was reached in the Lockyer Valley at Laidley; the flood wave moved towards the Brisbane River reaching $15 \mathrm{~m}$ in the Lockyer Creek (station 143207A, O’Reilleys Weir, Fig. 1) just before discharging into the Brisbane River. The resulting flood wave peaked at $12 \mathrm{~m}$ north of Brisbane City (Savages Crossing, Brisbane River station 143001C, Fig. 1), making the flood the 24th highest on record (ABM 2013; DERM). Between February 23th and March 4th, a second strong rainfall event (124 mm in one week) caused some minor flooding. During both floods, stream discharge increased considerably with peaks of 2,405 and $1,880 \mathrm{~m}^{3} \mathrm{~s}^{-1}$ for the first and second flood, respectively (DERM, station 143001C) (Fig. 2B). As part of the flood management, water from Somerset and Wivenhoe dam was systematically released during the flooding episodes (Fig. 2B, Seqwater). 
Sampling was conducted within the mid Brisbane River (-27.4929'S, 153.0184'E) from a

2 pontoon (Fig. 1). Rainwater was collected with a two-litre open container on the 27th and 28th

3 of January, 2013. These were the days with the highest recorded rainfall in Brisbane during

4 our sampling with 55 and $145 \mathrm{~mm}$, respectively (ABM, 2013). The container was left 4-5 hours

5 and the water was collected while the rain was falling in order to avoid evaporation. Rainwater

6 was poured in $50 \mathrm{~mL}$ plastic containers and kept cool until analysis. Floodwater was collected

7 every 2-3 hours from the river for the first three days of the first flood, then three times a day

8 until the 1st of February. Afterwards, weekly samples were collected until the $19^{\text {th }}$ of February,

9 when daily sampling was resumed for the second flood event (total $n=29$ ). River water was

10 collected in clean $500 \mathrm{~mL}$ polyethylene terephthalate (PET) bottles, which were rinsed with

11 surface water twice before sample collection at $20 \mathrm{~cm}$ below the water surface.

Conductivity and $\mathrm{pH}$ were recorded for each sample using an YSI-meter (Xylem Inc.

14 Ohio, USA). Mean daily conductivity, water temperature, rainfall and river discharge were

15 obtained from DERM (station 143001C, Fig. 1). Additionally, we included information on rainfall and river discharge from sampling stations $143203 \mathrm{C}$ and 143207A on Lockyer Creek, the tributary which contributed most to the flooding. Water samples were analysed for total suspended solids, dissolved nutrients ( $\mathrm{P}$ as orthophosphates, $\mathrm{N}$ as nitrous oxides, $\mathrm{N}-\mathrm{NO}_{\mathrm{x}}{ }^{-}$, and ammonium, $\mathrm{NH}_{4}{ }^{+}$), $\delta \mathrm{D}$ and $\delta^{18} \mathrm{O}$. Total suspended solids (TSS) were calculated by filtering a 20 known volume of water through pre-weighed $47 \mathrm{~mm}$ glass microfibre GF/C Whatman filters of $211.2 \mu \mathrm{m}$ pore size. Nutrients were analysed with EPA methods: 353.2 for NOx, 350.1 for $\mathrm{NH}_{4}{ }^{+}$, 22 and OP5A for $\mathrm{P}$ (SM-4500). Nutrient analysis detection limits were $0.005 \mu \mathrm{mol} \mathrm{L}^{-1}$ for $\mathrm{P}$ and $\mathrm{N}$ $23 \mathrm{NO}_{\mathrm{x}}{ }^{-}$, and $0.01 \mu \mathrm{mol} \mathrm{L}{ }^{-1}$ for $\mathrm{NH}_{4}{ }^{+}$. Nutrient loads were estimated from nutrient concentrations 24 and mean river discharge during the flood wave. 
$1 \quad$ For $\delta \mathrm{D}$ and $\delta^{18} \mathrm{O}$ analyses, rain and floodwater samples were kept in clean plastic

2 bottles with minimum air space and in cool conditions to avoid evaporation before analysis.

3 The water samples were analysed using a laser-based isotope analyser (LGR, Los Gatos

4 Research, CA, USA). Measurements were calibrated with international standards SMOW,

5 GISP, and SLAP, as well as five manufacture-supplied standards LGR1-LGR5 (Ahmad et al.

6 2012). The isotope values had errors (SD) $<2.0 \%$ for $\delta D$ and $<0.3 \%$ for $\delta^{18} \mathrm{O}$. Conductivity

7 was measured for each sample prior to analyses to avoid erratic results due to high salinity.

8 Conductivity readings for all samples were below $1000 \mu \mathrm{S} \mathrm{cm}{ }^{-1}$ with the majority below $250 \mu \mathrm{S}$

$9 \mathrm{~cm}^{-1}$, and were thus considered freshwater. Particulate organic matter was filtered out before

10 analyses with nylon syringe filters of $0.22 \mu \mathrm{m}$ pore size (Livingstone Int., NSW Australia).

11 Liquid organic contamination was possible, although likely to be minor as most of the

12 floodwater is derived from rain (Turner et al., 1987), most pollution from the Brisbane

13 catchment derives from agriculture, not industrial sources (Healthy Waterways, 2014), and the

14 sampling site was upstream of most of metropolitan Brisbane and its waste water discharges.

15 Deuterium excess ( $d$ excess) was calculated as: $d$ excess $(\%)=\delta D-8^{*} \delta^{18} \mathrm{O}$ (Dansgaard,

16 1964). The $d$ excess is an index of variation from the global meteoric water line (GMWL) and

17 can be used to understand the prevailing conditions during the evolution of air masses as

18 precipitation forms (Froehlich et al., 2002). Averages are reported as mean with standard

19 errors, unless otherwise stated.

Long-term precipitation data for the Brisbane region was obtained from the International

22 Atomic Energy Agency/ Water Resource Program, the Global Network of Isotopes in

23 Precipitation (Brisbane Station, IAEA/WMO, GNIP database 1962-2002, at:

$24 \mathrm{http}: / / \mathrm{www}$.iaea.org/water). From this dataset we calculated the local meteoric water line 
1 (LMWL). Seasonal predictions of the isotopic composition of precipitation were obtained from

2 Bowen et al. (2014).

3

4 Results at the peak of the major flood and to 6.77 at the peak of the minor flood (Fig. 2D).

Floodwater had large amounts of TSS, especially during the major flood when values 13 reached $1.5 \mathrm{~g} \mathrm{~L}^{-1}$ (pre-flood conditions were $<0.1 \mathrm{~g} \mathrm{~L}^{-1}$, Ozcoast, 2015). During the minor 14 flood, TSS reached a maximum value of $0.3 \mathrm{~g} \mathrm{~L}^{-1}$ (Fig. 2E). Total sediment loads were more 15 than double in the major flood with 481,266 tonnes or $28,148 \pm 10,689$ tonnes $d^{-1}$ compared to

Floodwater had high dissolved nutrient concentrations. During the major flood,

23 floodwater had maximum concentrations of $9 \mu \mathrm{mol} \mathrm{L}^{-1}$ for $\mathrm{P}, 42 \mu \mathrm{mol} \mathrm{L^{-1 }}$ for $\mathrm{N}-\mathrm{NO}_{\mathrm{x}}{ }^{-}$and 16

$24 \mu \mathrm{mol} \mathrm{L}{ }^{-1}$ for $\mathrm{N}_{-\mathrm{NH}_{4}}{ }^{+}$(Fig 2F). These concentrations are equivalent to $9 \pm 2$ tonnes $\mathrm{d}^{-1}$ of $\mathrm{P}, 288$ $25 \pm 62$ tonnes $\mathrm{d}^{-1}$ of $\mathrm{N}-\mathrm{NO}_{\mathrm{x}}{ }^{-}$and $21 \pm 5$ tonnes $\mathrm{d}^{-1}$ of $\mathrm{N}-\mathrm{NH}_{4}{ }^{+}$. During the minor flood, only $\mathrm{N}-\mathrm{NO}_{\mathrm{x}}{ }^{-}$ 


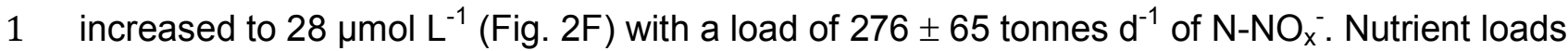

2 during floods, especially during the major flood, were more than 10 times larger than base flow

3 conditions for $\mathrm{P}$ and $\mathrm{N}^{-\mathrm{NO}_{\mathrm{x}}}{ }^{-}$, and almost 50 times larger for $\mathrm{N}^{-\mathrm{NH}_{4}}{ }_{4}$; base flow values for $\mathrm{P}, \mathrm{N}-$

$4 \quad \mathrm{NO}_{x}{ }^{-}$and $\mathrm{N}-\mathrm{NH}_{4}{ }^{+}$are $0.7 \pm 0.3,28.3 \pm 10.2$ tonnes $^{-1}$, and $0.4 \pm 0.1$ tonnes $\mathrm{d}^{-1}$, respectively.

5 Thus every flood transports about $110 \pm 3$ tonnes of $\mathrm{P}, 3,245 \pm 210$ tonnes of $\mathrm{N}-\mathrm{NO}_{x}$ and 269

$6 \pm 19$ tonnes of $\mathrm{N}-\mathrm{NH}_{3}{ }^{+}$. This represents about $35 \%$ of the annual $\mathrm{P}$ and $208 \%$ of the annual $\mathrm{N}$

7 estimated for the Brisbane River (Ozcoasts, 2015).

The water isotope composition varied significantly as floodwater moved through the river (Fig. 2G,H, Table 1). Mean values for the major flood were $-33.8 \pm 2.5 \%$ for $\delta \mathrm{D}$ and $-5.1 \pm$

$110.4 \%$ for $\delta^{18} \mathrm{O}$. Minimum and maximum values at this time were $-43.7 \%$ and $-20.3 \%$ for $\delta \mathrm{D}$ 12 and $-6.7 \%$ and $-3.1 \%$ for $\delta^{18} \mathrm{O}$. There were high $\delta \mathrm{D}$ and $\delta^{18} \mathrm{O}$ values at the beginning of the 13 flood and a few days after the flood peak, probably due to water release from the Wivenhoe14 Somerset dam (Seqwater, 2013; Fig. 2B). Prior to the flood, lake water in this large reservoir 15 probably had increased $\delta \mathrm{D}$ and $\delta^{18} \mathrm{O}$ values due to evaporation as this data fell off the GMWL 16 and the LMWL (black circles, Fig. 3), as expected for evaporated waters. During the minor 17 flood, water isotopic composition was also low, but less than during the major flood. Mean 18 values during the minor flood were $-29.4 \pm 1.0 \%$ for $\delta \mathrm{D}$ and $-4.6 \pm 0.1 \%$ for $\delta^{18} \mathrm{O}$, with 19 minimum and maximum values of -33.6 and $-27.0 \%$ for $\delta \mathrm{D}$, and $-5.3 \%$ and $-4.3 \%$ for $\delta^{18} \mathrm{O}$. For 20 comparison, mean values for precipitation in Brisbane during January and February are -15.0 $21 \pm 1.9 \%$ for $\delta \mathrm{D}$ and $-3.3 \pm 0.2 \%$ for $\delta^{18} \mathrm{O}$ (Brisbane Station, IAEA/WMO, GNIP 1962-2002).

In a dual isotope diagram, the data collected during this study had a wide range of

24 values (range of $36 \%$ for $\delta \mathrm{D}$ and $6 \%$ for $\delta^{18} \mathrm{O}$ ) and some of the data points from the first day of 25 the major flood deviated from the GMWL and LMWL (grey circles, Fig. 4). The lowest and 
1 highest $d$ excess values were measured during the peak of the major flood and had respective

2 values of 1.6 and $14.5 \%$ (Fig. 2I). For comparison, mean $d$ excess values for precipitation in

3 Brisbane during January and February are $12.2 \pm 0.5 \%$ (Brisbane Station, IAEA/WMO, GNIP

$4 \quad 1962-2002)$

5

6

The isotope composition of rainfall was different between flooding events. During the

7 major flood accompanying the tropical storm, rainfall had a mean $\delta \mathrm{D}$ value of $-36.1 \pm 6.3 \%$ o

8 and a mean $\delta^{18} \mathrm{O}$ value of $-5.6 \pm 07 \%$; during the minor flood, mean rainfall $\delta \mathrm{D}$ values were -

$9 \quad 18 \%$ and rainfall $\delta^{18} \mathrm{O}$ values were $-3.8 \%$ (Table 1 ). River values followed the isotope

10 composition of floodwater, indicating that most of the water during the peak flood was rain. The

11 values from the rainfall during the major flood were $20 \%$ lower for $\delta D$ and $2.3 \%$ lower for $\delta^{18} \mathrm{O}$

12 compared to the long-term mean values for January and February. The isotopic value of

13 rainfall during the minor flood was similar to the long-term monthly mean.

The historical data (1962-2002, IAEA/WMO, GNIP) shows that most flooding events in

16 the Brisbane region, some of them resulting from tropical storms, are associated to rainfall with

17 low isotope composition (Fig. 4A). Therefore, tropical storms in the region could partly explain

18 the high variability of monthly values of long-term data that has standard deviations of 14.3 for

$19 \delta \mathrm{D}$ and 1.7 for $\delta^{18} \mathrm{O}$ (Fig. 4B). Overall, there was a long-term trend of low water isotopic

20 composition accompanying high rainfall amounts (Fig. 4C).

\section{Discussion}

23 Floods throughout southeast Australia are major disruptions to riverine and coastal 24 ecosystems (Olds et al., 2014). In this study, we have shown that tropical storms in Brisbane 25 Australia have distinctly low isotope compositions, twice as low as the long-term mean for the 
1 region. The distinct isotope value of the rain was traced in the floodwater as it moved through

2 the river towards the coastal zone. The low isotope composition of the floodwater was

3 associated with the transport of large quantities of suspended sediments, with sediment loads

430 to 70 times larger than during base flow conditions. The floods also carried up to $35 \%$ of the

5 annual P and up to $208 \%$ of the calculated mean annual $\mathrm{N}$ load of the Brisbane River. These

6 dramatic changes were caused by a rapid flow increase, from 2 to $2,015 \mathrm{~m}^{3} \mathrm{~s}^{-1}$ in two days

7 during the onset of the major flood in the Lockyer Valley. These changes would have major

8 consequences in riverine and coastal ecosystems of the region and could be traced using the

9 specific water isotopic composition of floodwaters.

Measuring the isotope composition of floodwater could help trace flood effects on

12 riverine and coastal ecosystems. For example, during a tropical storm, mangroves can rapidly

13 take up floodwater and nutrients that can be traced in the plant tissues (Feakins and Sessions

14 2010; Lovelock 2011). Similarly, aquatic molluscs can acquire the isotope composition of

15 floodwater within days (Bortolotti et al., 2013), so that the subsidy effect of floods to aquatic

16 foodwebs could be estimated. The effects of flooding could also be used to estimate fish

17 growth and movement using high-resolution analyses of $3-5$ days of $\delta^{18} \mathrm{O}$ in fish otoliths

18 (Patterson, 1998; Walther and Thorrold, 2009). Additionally, seasonal variations in $\delta^{18} \mathrm{O}$ in

19 cave speleothems have been associated with the frequency of intense rainfall events (Treble

20 et al., 2005). Thus, summers of intense activity, such as the austral summer of 1976 (Fig 4A)

21 could produce significant changes in the seasonal $\delta^{18} \mathrm{O}$ mean of palaeoecological records

22 (Treble et al., 2005).

23

24 The water isotope composition of rainfall during other tropical storms also has been 25 reported to be low. For example, during the passage of Hurricane Sandy, a category-three 
1 hurricane in the eastern United States, rivers and rainfalls had low $\delta \mathrm{D}$ values of $-40 \%$ and -50

$2 \%$, respectively (Higgins, 2012). These values were $20-25 \%$ lower than the regional

3 background values (Higgins, 2012). The floodwater from our study had a wide range of

4 isotopic values, $23 \%$ for $\delta D$ and of $3.6 \%$ for $\delta^{18} \mathrm{O}$ during the major flood. This suggests large

5 variations in water source and/or precipitation mechanisms (Bowen, 2012). Datasets from

6 tropical storms, including ours, show a large range in $d$ excess values with many points lying

7 well below and above the GMWL (Bowen, 2012).

8

After the flood peak, the isotopic composition of floodwater was influenced by the water released as part of flood management of the dams upstream of our sampling point, resulting in an increase in the isotopic composition of floodwater. Without the influence of the dam, the curve of change of the isotopic composition of the floodwater likely would have remained low for longer. The influence of water releases from dams is likely to dilute the flood signal in dammed rivers. Nevertheless, during the flood peak, the isotopic composition of floodwater was very close to that of rain, indicating that the composition of the flood during its peak is representative of floodwater from the tropical storm.

In conclusion we found that during a tropical storm in Brisbane Australia and the floods that followed it, rain and floodwater were characterized by low water $\delta \mathrm{D}$ and $\delta^{18} \mathrm{O}$ isotopes compared to regional mean values. The distinct isotopic value of the rainfall could be followed into the river and floodwater as the flood moved to the coastal zone carrying large quantities of suspended sediments, and dissolved nutrients. The increased knowledge of $\delta D$ and $\delta^{18} O$ values during tropical storms and flooding may lead to better understandings of hydrological oscillations and the ecological consequences of extreme weather events. 


\section{Acknowledgements}

2 We thank the Australian Rivers Institute at Griffith University for financial and logistic support.

3 We acknowledge T. Brennan, E. Miller, C. Doropoulous, E. Marcellin, C. Licona and M. Brunck

4 for field assistance. We thank J. McMahon for revising this manuscript. 5 


\section{References}

ABM, Australian Bureau of Meteorology

http://www.bom.gov.au/qld/flood/fld_history/brisbane_history.shtml Accessed 10 June, 2015

ABM, Australian Bureau of Meteorology. 2013. Special climate statement 44 - extreme rainfall and flooding in coastal Queensland and New South Wales. Commonwealth of Australia. Bureau of Meteorology; pp.14

Ahmad M, Aggarwal P, van Duren M, Poltenstein L, Araguas L, Kurttas T, Wassenaar LI. 2012. Final report on fourth interlaboratory comparison exercise for $\delta D$ and $\delta^{18} O$ analysis of water samples (WICO2011). International Atomic Energy Agency, Vienna, Austria. 63 $\mathrm{pp}$

Araguás-Araguás L, Froehlich K, Rozanski K. Deuterium and oxygen-18 isotope composition of precipitation and atmospheric moisture. 2000. Hydrological Processes 14: 1341-1355

Bortolotti LE, Clark RG, Wassenaar LI. 2013. Hydrogen isotope variability in prairie wetland systems: implications for studies of migratory connectivity. Ecological applications 23: 110-121

Bowen GJ, Wassenaar LI, Hobson KA. 2005. Global application of stable hydrogen and oxygen isotopes to wildlife forensics. Oecologia 143: 337-348

Bowen GJ. 2012. http://wateriso.utah.edu/waterisotopes/pages/data_access/ghd.html. Accessed February 2014

Bowen GJ. 2014. The online isotopes in precipitation calculator http://www.waterisotopes.org. Accessed February 2014

Campbell SJ, McKenzie LJ. 2004. Flood related loss and recovery of intertidal seagrass meadows in southern Queensland, Australia. Estuarine Coastal and Shelf Science 60: 477-490. DOI: 10.1016/j.ecss.2004.02.007

Dansgaard W. 1964. Stable isotopes in precipitation. Tellus XVI 4: 436-468

Dawson TE, Mambelli S, Plamboeck H, Templer PH, Tu KP. 2002. Stable isotopes in plant ecology. Annual Review of Ecology and Systematics 33: 507-559

DERM, Department of Natural Resources and Mines, State of Queensland, http://watermonitoring.dnrm.qld.gov.au/host.htm. Accessed 22 October, 2014

Ehtesham E, Baisden WT, Keller ED, Hayman AR, Van Hale R, Frew RD. 2013. Correlation between precipitation and geographical location of the $\delta^{2} \mathrm{H}$ values of the fatty acids in milk and bulk milk powder. Geochimica et Cosmochimica Acta 111: 105-116

Feakins SJ, Sessions AL. 2010. Controls on the D/H ratios of plant leaf waxes in an arid ecosystem. Geochimica et Cosmochimica Acta 74: 2128-2141 
1 Froehlich K, Gibson JJ, Aggarwal P. 2002. Deuterium excess in precipitation and its climatological significance. Study of environmental change using isotope techniques. C\&S Papers Series 13/P. 54-65. International Atomic Energy Agency: Vienna, Austria

Gat JR. 1996. Oxygen and hydrogen isotopes in the hydrologic cycle. Annual Review of Earth Planet Science 24: 225-262. DOI: 10.1146/annurev.earth.24.1.225

Hallock P, Schlager W. 1996. Nutrient excess and the demise of coral reefs and carbonate platforms. Palaios 1: 389-398

Healthy waterways Australia. http://healthywaterways.org Accesed 10 June, 2015.

Higgins P. 2012. http://paleopix.com/blog/2012/11/07/more-about-sandy/. Accesed September, 2014

Hobson KA, Wassenaar LI. 1997. Linking breeding and wintering grounds of neotropical migrant songbirds using stable hydrogen isotopic analysis of feathers. Oecologia 109: 142-148

IAEA/WMO. 2015. Global Network of Isotopes in Precipitation. The GNIP Database. http://www.iaea.org/water. Accessed 10 June, 2015

Kurita N, Ichiyanagi K, Matsumoto J, Yamanaka MD, Ohata T. 2009. The relationship between the isotopic content of precipitation and the precipitation amount in tropical regions. Journal of Geochemical Exploration 102: 113-122. DOI: 10.1016/j.gexplo.2009.03.002

Lachniet MS, Patterson WP. 2009. Oxygen isotope values of precipitation and surface waters in northern Central America (Belize and Guatemala) are dominated by temperature and amount effects. Earth and Planetary Science Letters 284: 435-446

Lovelock CE, Feller IC, Adame MF, Reef R, Penrose H, Wei L, Ball MC. 2011. Intense storms and the delivery of materials that relieve nutrient limitations in mangroves of an arid zone estuary. Functional Plant Biology 38: 514-522

Matsui E, Salati E, Ribeiro MNG, Reis CM, Tancredi ACSNF, Gat JR. 1983. Precipitation in the Central Amazon Basin: The isotopic composition of rain and atmospheric moisture at Belem and Manaus. Acta Amazonica 13: 307-369

Mitchell AW, Bramley RGV, Johnson AKL. 1997. Export of nutrients and suspended sediment during a cyclone-mediated flood event in the Herbert River catchment, Australia. Marine and Freshwater Research 48: 79-88

Olds AD, Pitt K, Maxwell PS, Babcock RC, Rissik D , Connolly RM. 2014. Marine reseves help coastal ecoystems cope with extreme weather. Global Change Biology 20: 3050-3058

Ozcoasts, Australian online coastal information. Geoscience Australia. http://www.ozcoasts.gov.au/index.jsp Accessed 10 June, 2015

Paerl H. 2008. Nutrient and other environmental controls of harmful cyanobacterial blooms along the freshwater-marine continuum. Cyanobacterial harmful algal bloom. State of the 
Science and Research Needs Advances in Experimental Medicine and Biology. Springer, New York, U.S.A. 618: 217-37

Patterson WP. 1998. North American continental seasonality during the last millennium: highresolution analysis of sagittal otoliths. Palaeography, Paleaoclimatology, Palaeoecology 138: $271-303$.

Seqwater. Report on the operation of Somerset Dam and Wivenhoe Dam. January 2013, flood event. 251 pp. Queensland government, Australia

Scholl MA., Shanley JB, Zegarra JP, Coplen TB. 2009. The stable isotope amount effect: New insights from NEXRAD echo tops, Luquillo Mountains, Puerto Rico. Water Resource Research 45: 1-14. DOI: 10.1029/2008WR007515

Shellberg J, Brooks, A. 2007. A fluvial audit of the upper Brisbane River: A basis for assessing catchment disturbance, sediment production and rehabilitation potential. Brisbane, Griffith University

Turner JV, Macpherson DK, Stokes RA. 1987. The mechanisms of catchment flow processes using natural variations in deuterium and oxygen-18. Journal of Hydrology 94: 143-162

Walther BD, Thorrold SR. 2009. Inter-annual variability in isotope and elemental ratios recorded in anadromous fish. Journal of Geochemical Exploration 102: 181-186 
Table 1. $\delta \mathrm{D}, \delta^{18} \mathrm{O}(\%)$ and $d$ excess values of floodwater and rain during two flood events in the Brisbane River in 2013. Values are mean \pm standard deviations of replicates within the same sample.

\begin{tabular}{|c|c|c|c|c|}
\hline Date & Sampling time & $\delta \mathrm{D}(\%)$ & $\delta^{18} \mathrm{O}(\%)$ & $d$ excess \\
\hline \multicolumn{5}{|c|}{ Floodwater } \\
\hline \multicolumn{5}{|c|}{$1^{\text {st }}$ flood } \\
\hline \multirow[t]{4}{*}{ 27-Jan } & 11:00 & $-7.8 \pm 1.3$ & $-1.3 \pm 0.2$ & 2.5 \\
\hline & $15: 00$ & $-7.2 \pm 0.5$ & $-1.2 \pm 0.1$ & 2.2 \\
\hline & $19: 15$ & $-13.9 \pm 0.3$ & $-2.2 \pm 0.0$ & 3.4 \\
\hline & $21: 45$ & $-17.0 \pm 0.4$ & $-3.9 \pm 0.2$ & 14.5 \\
\hline \multirow[t]{4}{*}{ 28-Jan } & $9: 30$ & $-27.2 \pm 2.2$ & $-4.3 \pm 0.3$ & 7.3 \\
\hline & $15: 00$ & $-30.6 \pm 0.2$ & $-4.9 \pm 0.0$ & 8.3 \\
\hline & $18: 00$ & $-33.4 \pm 1.0$ & $-5.2 \pm 0.2$ & 8.5 \\
\hline & $21: 00$ & $-41.4 \pm 0.9$ & $-5.6 \pm 0.0$ & 3.8 \\
\hline \multirow[t]{3}{*}{ 29-Jan } & $7: 30$ & $-41.4 \pm 1.1$ & $-6.5 \pm 0.1$ & 10.6 \\
\hline & $12: 30$ & $-42.8 \pm 1.0$ & $-6.7 \pm 0.2$ & 10.6 \\
\hline & $18: 15$ & $-43.7 \pm 0.7$ & $-6.4 \pm 0.1$ & 7.9 \\
\hline \multirow[t]{2}{*}{ 30-Jan } & $7: 30$ & $-33.0 \pm 2.3$ & $-4.3 \pm 0.3$ & 1.6 \\
\hline & $18: 00$ & $-20.3 \pm 1.1$ & $-3.1 \pm 0.1$ & 4.4 \\
\hline 31-Jan & $18: 00$ & $-21.8 \pm 1.4$ & $-3.4 \pm 0.2$ & 5.3 \\
\hline $1-F e b$ & $7: 45$ & $-36.1 \pm 1.1$ & $-5.5 \pm 0.2$ & 7.6 \\
\hline \multicolumn{5}{|c|}{ Inter floods } \\
\hline 9-Feb & $10: 00$ & $-17.5 \pm 0.5$ & $-3.8 \pm 0.1$ & 13.3 \\
\hline 15-Feb & $8: 10$ & $-24.6 \pm 0.3$ & $-4.4 \pm 0.2$ & 10.4 \\
\hline 19-Feb & $18: 00$ & $-22.1 \pm 0.5$ & $-4.1 \pm 0.1$ & 10.5 \\
\hline 20-Feb & $19: 20$ & $-20.9 \pm 0.4$ & $-3.5 \pm 0.1$ & 7.5 \\
\hline \multicolumn{5}{|l|}{$2^{\text {nd }}$ flood } \\
\hline 23-Feb & $14: 45$ & $-24.1 \pm 0.6$ & $-4.1 \pm 0.1$ & 8.7 \\
\hline \multirow[t]{2}{*}{ 24-Feb } & $10: 45$ & $-22.3 \pm 0.3$ & $-3.9 \pm 0.3$ & 8.5 \\
\hline & $15: 30$ & $-25.7 \pm 1.2$ & $-4.2 \pm 0.3$ & 7.6 \\
\hline 25-Feb & $18: 20$ & $-24.7 \pm 0.5$ & $-3.9 \pm 0.3$ & 6.6 \\
\hline \multirow[t]{2}{*}{ 26-Feb } & $7: 50$ & $-27.9 \pm 0.4$ & $-4.5 \pm 0.1$ & 8.0 \\
\hline & $19: 20$ & $-27.0 \pm 0.9$ & $-4.3 \pm 0.3$ & 7.3 \\
\hline \multirow[t]{2}{*}{ 27-Feb } & $7: 50$ & $-33.6 \pm 0.5$ & $-5.3 \pm 0.3$ & 8.4 \\
\hline & $18: 30$ & $-31.1 \pm 0.6$ & $-4.8 \pm 0.2$ & 7.4 \\
\hline \multirow[t]{2}{*}{ 28-Feb } & $8: 20$ & $-28.5 \pm 0.7$ & $-4.6 \pm 0.2$ & 8.2 \\
\hline & $16: 50$ & $-28.1 \pm 0.7$ & $-4.4 \pm 0.3$ & 7.2 \\
\hline \multicolumn{5}{|l|}{ Rain } \\
\hline \multicolumn{5}{|l|}{$1^{\text {st }}$ flood } \\
\hline \multirow[t]{3}{*}{ 27-Jan } & $13: 00$ & $-32.3 \pm 0.8$ & $-5.1 \pm 0.2$ & 8.7 \\
\hline & $17: 00$ & $-47.4 \pm 1.3$ & $-6.9 \pm 0.2$ & 8.0 \\
\hline & 21:45 & $-33.2 \pm 1.1$ & $-5.4 \pm 0.2$ & 10.1 \\
\hline \multirow[t]{2}{*}{ 28-Jan } & $9: 30$ & $-15.9 \pm 1.8$ & $-3.2 \pm 0.2$ & 9.3 \\
\hline & 21:00 & $-51.6 \pm 0.5$ & $-7.2 \pm 0.2$ & 6.2 \\
\hline \multicolumn{5}{|c|}{$2^{\text {nd }}$ flood } \\
\hline 26-Feb & 7:50 & $-18.9 \pm 0.6$ & $-3.8 \pm 0.5$ & 11.7 \\
\hline
\end{tabular}




\section{$1 \quad$ Figure legends}

2 Figure 1. Sampling location within the Brisbane River (cross), long-term GNIP station

3 (Brisbane City station, IAEA/WMO), and sampling stations for rainfall, river discharge,

4 conductivity, $\mathrm{pH}$ and water temperature (DERM, State of Queensland).

6 Figure 2. (A) Daily rainfall $(\mathrm{mm})$ in the upper Brisbane River (station 143001C) and in the

7 Lockyer Creek (station 143203C), (B) river discharge $\left(\mathrm{m}^{3} \mathrm{~s}^{-1}\right.$, stations $143001 \mathrm{C}$ and $\left.143207 \mathrm{~A}\right)$

8 and releases from Wivenhoe-Somerset dam, (C) daily mean conductivity $\left(\mu \mathrm{Sm}^{-1}\right)$,

9 temperature $\left({ }^{\circ} \mathrm{C}\right)$ at station $143001 \mathrm{C},(\mathrm{D}) \mathrm{pH} ;(\mathrm{E})$ total suspended solids (TSS; $\left.\mathrm{g} \mathrm{L}^{-1}\right) ;(\mathrm{F})$

10 dissolved nutrients: orthophosphates, $\mathrm{P}$, nitrogen as nitrogen oxides, $\mathrm{N}-\mathrm{NO}_{\mathrm{x}}^{-}$, and nitrogen as

11 ammonium, $\mathrm{N}-\mathrm{NH}_{4}{ }^{+}\left(\mu \mathrm{mol} \mathrm{L}{ }^{-1}\right)$, and DIN:DIP, (G) $\delta \mathrm{D} \%$ o, $(\mathrm{H}) \delta^{18} \mathrm{O} \%$ (vs. V-SMOW) of

12 floodwater collected from the Brisbane River and rain, and (I) $d$ excess. Dashed lines

13 represent expected TSS, dissolved nutrients and isotopic composition baselines as predicted

14 by Ozcoasts, Healthy Waterways and Bowen et al. (2014). Data for rainfall, river discharge,

15 temperature and conductivity was obtained from the Department of Natural Resources and

16 Mines, Brisbane River stations. Data from dam Wivenhoe-Somerset dam releases were

17 obtained from Seqwater. Ph, TSS, nutrients and isotope values were measured by the authors

18 from the Brisbane River sampling point (see Fig. 1).

20 Figure 3. Floodwater $\delta \mathrm{D}$ and $\delta^{18} \mathrm{O}$ (\%o vs. V-SMOW) plotted against the global meteoric water 21 line (GMWL) and the local meteoric water line (LMWL) calculated from the GNIP database 22 (Brisbane Station 1967-2002, IAEA/WMO). Black circles are values of floodwater during 23 release of water from the upstream dam (Wivenhoe-Somerset dam); grey circles are values 24 from the beginning of the major flood. 
1 Figure 4. (A) Long-term monthly $\delta D$ values of precipitation from 1972-2002 for the Brisbane

2 River, light grey bars represent moderate and minor floods, dark grey bars represent major

3 floods (ABM, 2015); (B) monthly mean from 1962-2002 and predicted values (dashed line,

4 Bowen 2014) of precipitation for Brisbane; (C) precipitation amount (log mm) against $\delta D$

5 values for Brisbane for 1962-2002. Data are from Brisbane Station, GNIP, IAEAMMO. 
Figure 1. Sampling location within the Brisbane River (cross), long-term GNIP station (Brisbane City station, IAEA/WMO), and sampling stations for rainfall, river discharge, conductivity, $\mathrm{pH}$ and water temperature (DERM, State of Queensland). $210 \times 296 \mathrm{~mm}(300 \times 300 \mathrm{DPI})$ 


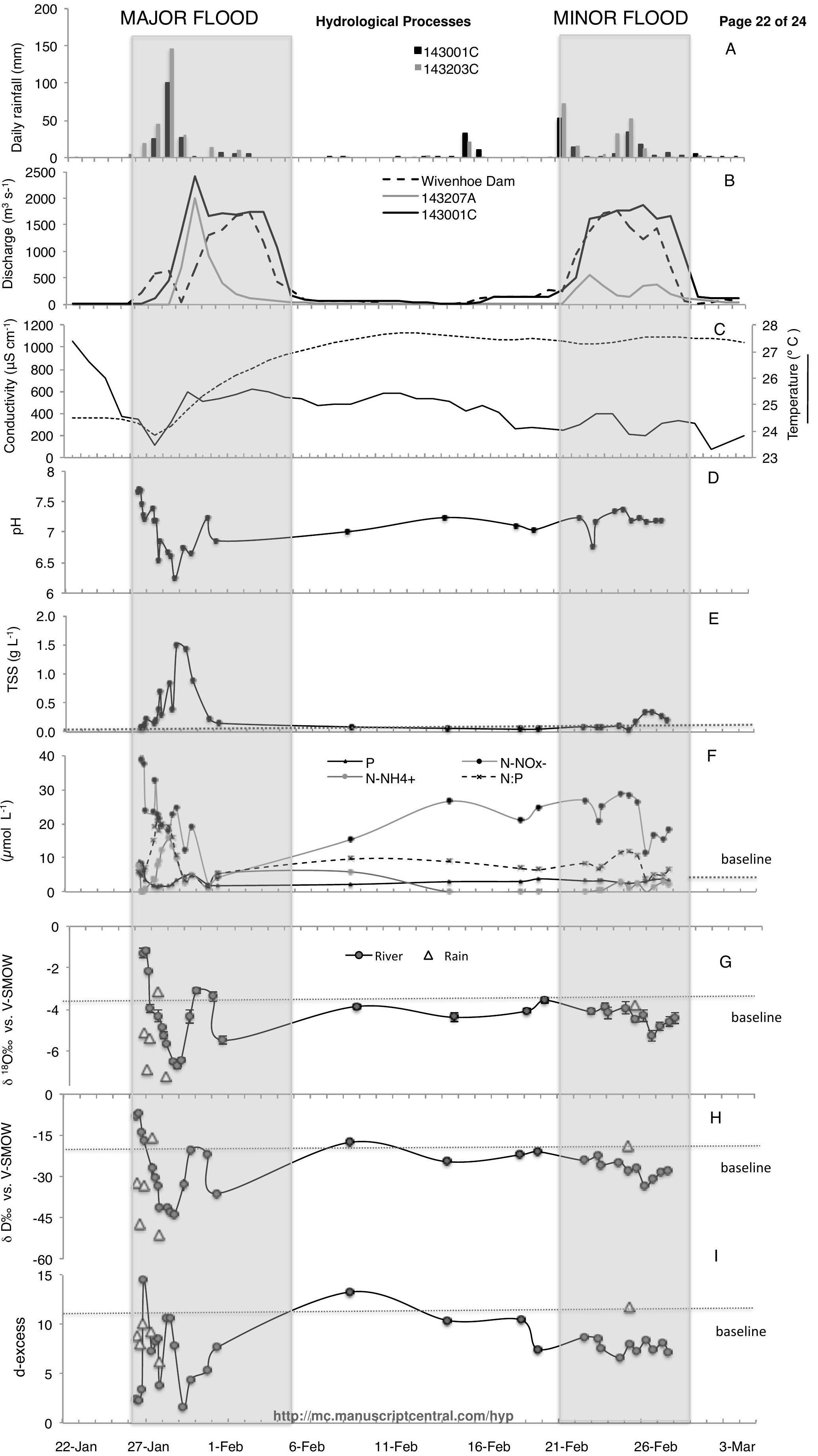


Page 23 of 24

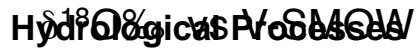

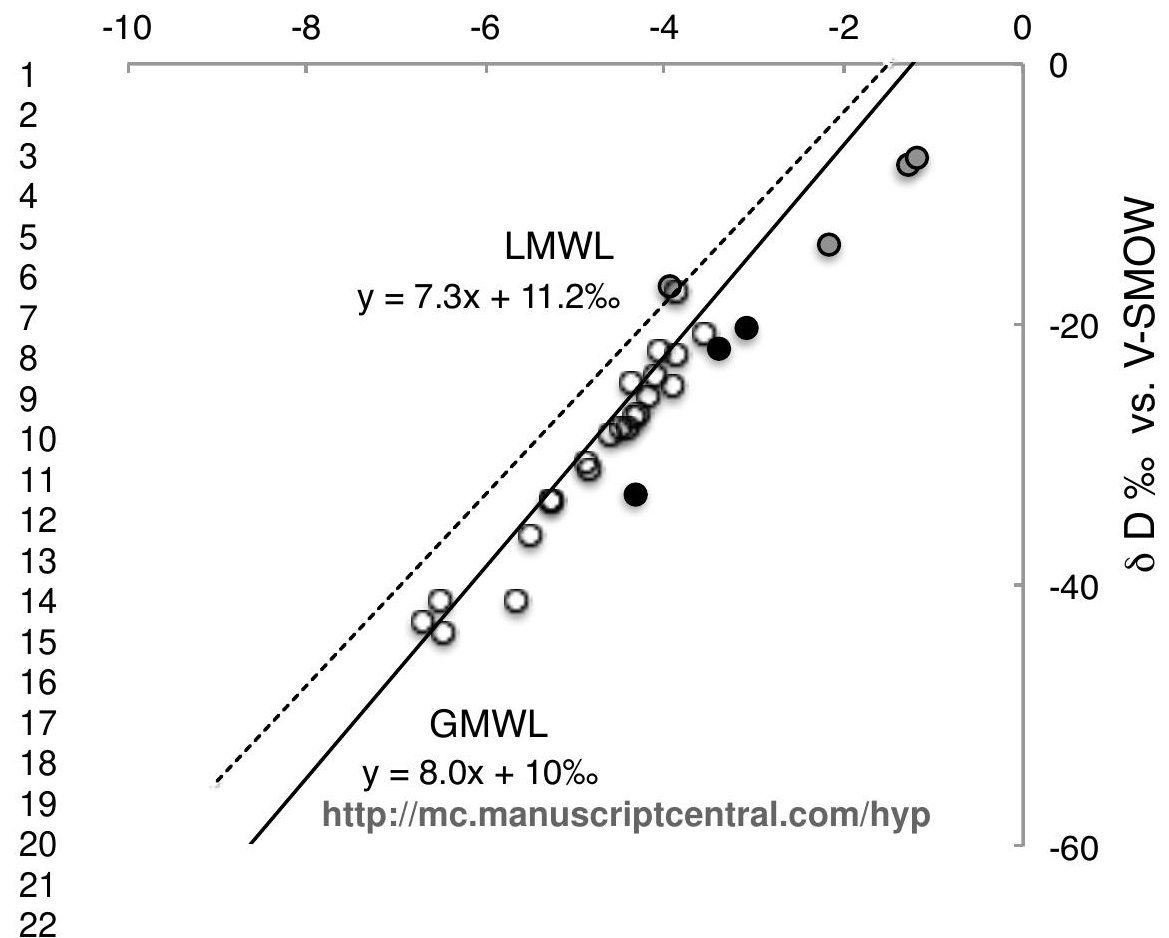




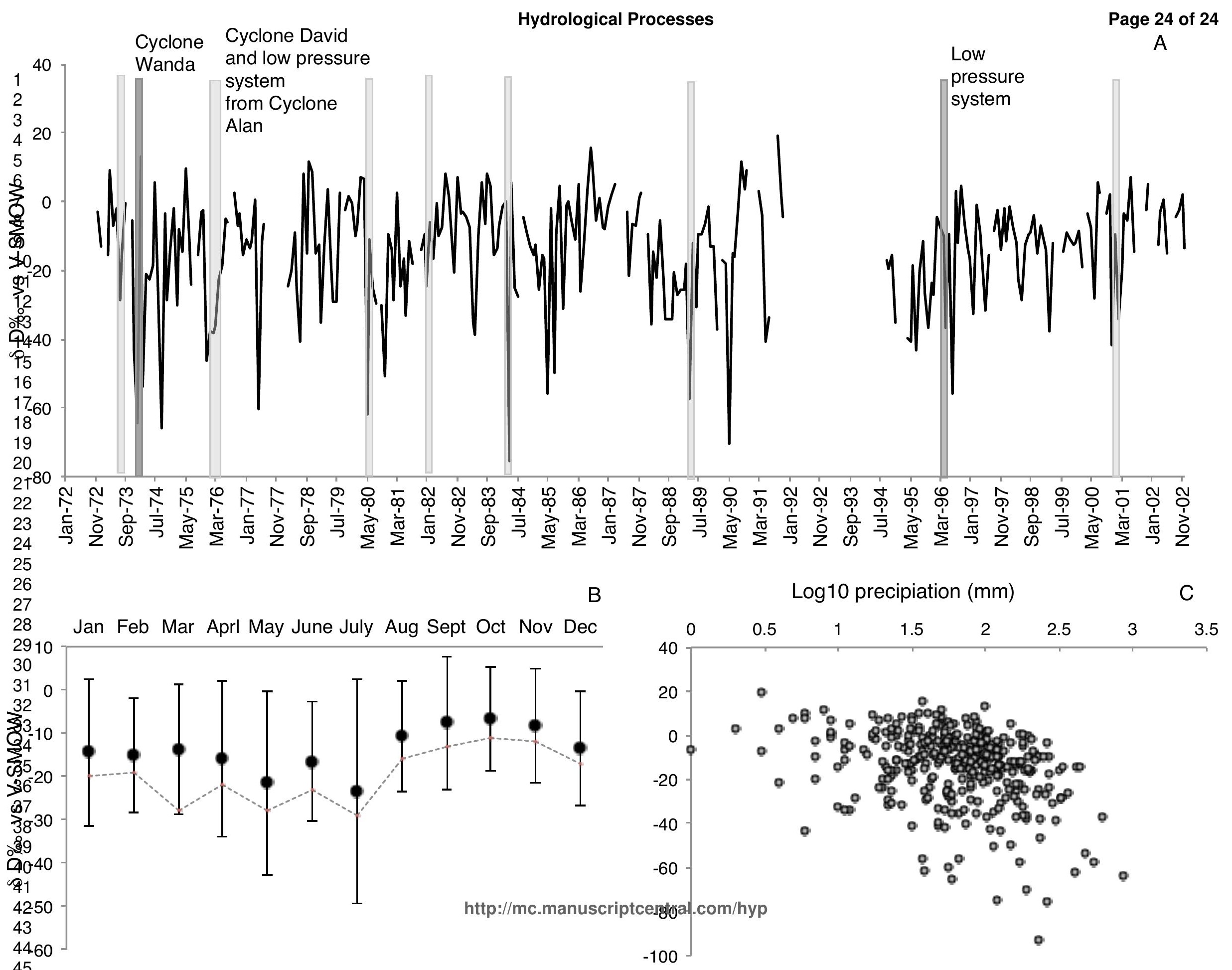

